\title{
SciDoC
}

Infer, Interpret \& Inspire Science

International Journal of Dentistry and Oral Science (IJDOS)

ISSN: $2377-8075$

\section{Periodontal Dressing After Flap Surgery -A Retrospective Study}

Research Article

Anisha A Mahtani ${ }^{1}$, Sheeja Varghese ${ }^{2 *}$, Ravindrakumar Jain ${ }^{3}$

${ }^{1}$ Saveetha Dental College and Hospitals, Saveetha Institute of Medical and Technical Sciences, Saveetha University, Chennai, India.

${ }^{2}$ Professor, Department of Periodontics, Saveetha Dental College and Hospitals, Saveetha Institute of Medical and Technical Sciences, Saveetha University, Chennai, India.

${ }^{3}$ Professor, Department of Conservative Dentistry and Endodontics, Saveetha Dental College and Hospitals, Saveetha Institute of Medical and Technical Sciences, Saveetha University, Chennai, India.

\section{Abstract}

\begin{abstract}
Aim: The use of periodontal dressing (pack) post periodontal surgery has always been a dilemma and many authors have conducted studies to determine its need. The purpose of this study was to evaluate the effect of periodontal dressing on post-operative pain, swelling and healing after flap surgery. This would enable us to understand the significance of periodontal dressing and thereby decide if we should advocate its use in our clinical practices.

Materials and Methods: Digital case records of 734 patients who underwent flap surgery in the hospital from June 2019 to March 2020 were reviewed. All the pre and post op details including site of flap surgery and post operative healing were evaluated. Cases with incomplete data were excluded and narrowed down to 348 patients. The post-operative clinical photographs of 348 patients were evaluated and graded based on the Healing index of Landry, Turnbull and Howley. Descriptive statistics and tests of association were done by Chi square tests and unpaired t-test using IBM SPSS Software Version 20.0. P value $<$ 0.05 was considered statistically significant.

Results: Periodontal dressing was preferred $23 \%$ of the times amongst the dentists. A significant association indicating that non usage of Periodontal dressing provided better healing than usage of pack was revealed. $(p=0.037)$ Quadrant 1 was found to be the most commonly used site in flap surgeries.

Conclusion: Postoperativehealing is significantly better for flap surgeries done without the usage of periodontal dressing.
\end{abstract}

Keywords: Flap Surgery; Healing Index; Non Eugenol Pack; Periodontal Dressing.

\section{Introduction}

Periodontitis is a chronic bacterial infection characterized by persistent inflammation, connective tissue breakdown and alveolar bone destruction mediated by pro-inflammatory mediators [1-4]. This resultant microbial load and inflammation can have systemic implication as well $[5,6]$. The treatment of periodontitis includes both non surgical $[7,8]$ and surgical methods aimed at eliminating the periodontal pockets and regenerating the lost periodontium [9-14]. The two common soft tissue surgeries performed for the same are gingivectomy and flap surgeries. Protection of surgical wounds is an important aspect during the healing period as it can influence the outcome of the surgery.
Periodontal dressings were first introduced by Dr. A.W Ward in 1923. Since then, they have been used as surgical dressings in periodontal surgical wounds. Protecting the wound from mechanical trauma and stability of the surgical site during the healing process are important advantages of periodontal dressing application after surgery $[7,15,16]$. It also provides good adaptation to underlying gingival and bone tissue, prevents post-operative haemorrhage or infection and decreases tooth hypersensitivity in the first hours after surgery. The periodontal dressing is known to protect the clot from forces applied during speaking or chewing $[17,18]$.

A study done by Ghanbari et al., [19] revealed pain reduction after

*Corresponding Author:

Sheeja Varghese,

Professor, Department of Periodontics, Saveetha Dental College and Hospitals, Saveetha Institute of Medical and Technical Sciences, Saveetha University, Chennai, India. Tel: 9884042252

Email ID: sheejavarghese@saveetha.com

Received: February 25, 2021

Accepted: March 04, 2021

Published: March 09, 2021

Citation: Anisha A Mahtani, Sheeja Varghese, Ravindrakumar Jain. Periodontal Dressing After Flap Surgery -A Retrospective Study. Int J Dentistry Oral Sci. $2021 ; 08(03): 1932-1938$. doi: http://dx.doi.org/10.19070/2377-8075-21000383

Copyright: Sheeja Varghese ${ }^{\circ} 2021$. This is an open-access article distributed under the terms of the Creative Commons Attribution License, which permits unrestricted use, distribution and reproduction in any medium, provided the original author and source are credited. 
the usage of periodontal dressing. Moghareh Abed et al., [20] revealed the degree of post-surgical pain to be equal in patients with and without the periodontal dressing, however studies done by PS Newman [21] and TM Jones [22] showed severe pain and discomfort in the post-operatic site where the dressing was placed.

The dilemma on the usage of a periodontal dressing post-surgery is a highly debated topic till today and it varies from surgeon to surgeon depending on many factors.

Hence the aim of this study was to determine the number of flap surgeries performed with and without the dressing in a dental hospital to identify any commonly used site in flap surgeries and to determine whether there is any difference in postoperative healing in patients with and without the periodontal dressing usage.

\section{Materials and Methods}

\section{Study design and Study setting}

The present hospital-based retrospective study was carried out with the use of digital case records of 734 patients who underwent flap surgery from the lakhs of patients attending a dental hospital from June 2019 to March 2020. Ethical clearance to conduct this study was obtained from the Scientific Review Board of the hospital with the following ethical approval number - SDC/ SIHEC/2020/DIASDATA/0619-0320.

\section{Sampling}

After assessment in the university patient data registry, case records of 734 patients who underwent flap surgeries were included in the study. Consecutive sampling method was carried out. Cross verification of data for errors was done. Each case was verified regarding the general information of the patient, if periodontal dressing was used and post-operative evaluation by post-operative notes and clinical photographs. The exclusion criteria was missing or incomplete data.

\section{Data Collection}

Digital case records of the patients collected from June 2019 to March 2020 and evaluated. Exclusion criteria eliminated cases that had not mentioned if pack was used or not; cases with no postoperative evaluation and cases that were not approved by the concerned faculty in the hospital. From the 734 patients that underwent flap surgery, 348 cases were narrowed down following the exclusion criteria. If a single patient had undergone flap surgery for more than 2 sites, all the sites were taken individually and evaluated. The surgery performed was analysed quadrant and sextant wise. A single calibrated examiner evaluated the post-operative clinical photographs of the 348 patients and graded them based on the Healing Index of Landry, Turnbell and Howley. The healing index was scored from 1-5 with 1-Very poor; 2-Poor; 3-Good, 4-Very good and 5-Excellent.

\section{Statistical Analysis}

Qualitative analysis was done using Chi square tests and Quantitative analysis was performed with the help of Independent t-tests using Statistical Package for Social Sciences for Windows, Version 20.0 (SPSS Inc., Chicago, IL, USA). The independent variables used in the study were usage of periodontal dressing, type of periodontal dressing used, Quadrant or Sextant commonly used and general patient detail like age and gender. Dependent variable used was post-operative healing or complication. Descriptive analysis was carried out for the preference of periodontal dressing post flap surgery, type of dressing used if preferred and any particular sextants/quadrants preferred for placement of dressing. Chi Square test was performed to assess the difference in the influence of periodontal dressing on healing with the use of the qualitative scores graded as Very poor, Poor, Good, Very good and Excellent. Independent t-tests evaluated the healing index quantitatively based on the scores (1-5) allotted in relation to the usage of dressing. If $\mathrm{p}$ value was found to be $<0.05$, the relation was taken as significant.

\section{Results}

Out of 734 , only 348 patients were evaluated as they fulfilled the inclusion criteria.

Descriptive analysis of demographic data shows that flap surgeries were done in all the age groups wherein $4.3 \%$ below 20 years of age, $20.7 \%$ in the $21-30$ age group, $35.3 \%$ in the 31 to 40 year age group, $27.3 \%$ between $41-50$ years, $8.6 \%$ within $51-60$ years and $3.7 \%$ in the $61-70$ year age group. Majority were found between $31-40$ years of age. (Figure 1) The periodontal dressings were used for $23 \%$ of surgeries and not used $77 \%$ of the time (Table 1).

Based on the commonly used sites during flap surgery, Quadrant 1 was found to be the most commonly treated at $17 \%$, followed by Quadrant 2 at $14.4 \%$ and Quadrant 3 and 4 at $11.5 \%$. (Table 1) In all the sites there was a higher prevalence of preference for not using the periodontal dressing. Quadrant 1 and Quadrant 2 were the most commonly treated sites, but a drastic difference is noted in Quadrant 2 where the dressing was not preferred in 44 cases and was used only in 6. Statistical analysis showed that there is no significant association between bsage of periodontal dressings and the site of flap surgery $(\mathrm{p}=0.261)$. (Table 2, Figure 2 )

The study showed $59.2 \%$ of males and $40.8 \%$ of females that underwent flap surgeries (Table 1). On statistical comparison, no significant association between gender and post-operative healing was observed $(p=0.257)$ showing not much variation between the genders with respect to postoperative healing (Figure 3, Table 3).

While analysing the post operative healing index based on the usage of the periodontal dressing, majority of the cases that did not use a periodontal dressing had better healing as seen in Score, 5 - Excellent healing and Score 4 - Very good healing, with $28.79 \%$ and $24.5 \%$ of cases respectively. Score 1 - Very poor healing was seen by $8.49 \%$ of cases that used the periodontal dressing. The statistical analysis done qualitatively with chi square test provided statistically significant results with $p=0.037$ stating that 'no dressing' has better healing than usage of periodontal dressing. (Table 4, Figure 4)

The mean healing index with respect to the usage of periodontal 
Figure 1. Bar graph depicting the age wise frequency distribution of patients undergoing flap surgery. $\mathrm{X}$ axis represents the age distribution and $\mathrm{Y}$ axis represents the number of patients in each age group. Maximum patients $(35.3 \%)$ were found between $31-40$ years of age.

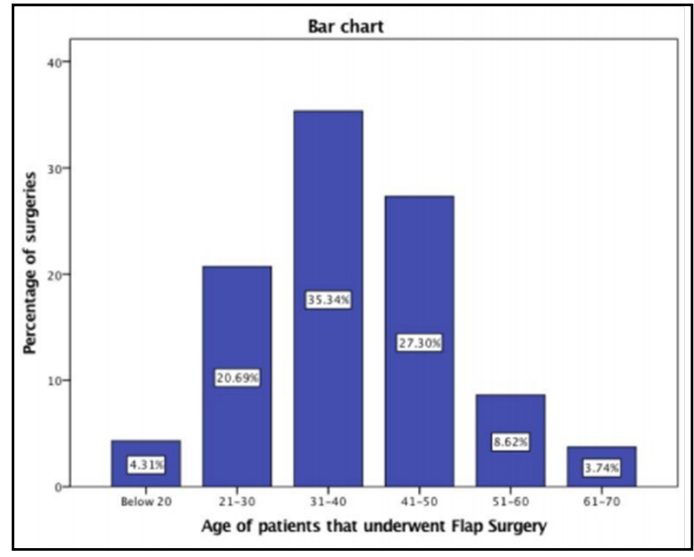

Table 1. Demographic details of the study population. Males underwent more flap surgeries than females. More flaps are in Upper quadrants and sextants than in lower. Periodontal dressing is not frequently used.

\begin{tabular}{|c|c|c|c|}
\hline FACTOR & GROUP & FREQUENCY (n) & PERCENTAGE \\
\hline \multirow[t]{6}{*}{ Age } & $<20$ & 15 & $4.30 \%$ \\
\hline & $21-30$ & 72 & $20.70 \%$ \\
\hline & $31-40$ & 123 & $35.30 \%$ \\
\hline & $41-50$ & 95 & $27.30 \%$ \\
\hline & $51-60$ & 30 & $8.60 \%$ \\
\hline & $>70$ & 13 & $3.70 \%$ \\
\hline \multirow[t]{2}{*}{ Gender } & Male & 206 & $59.20 \%$ \\
\hline & Female & 142 & $40.80 \%$ \\
\hline \multirow[t]{10}{*}{ Sites treated } & Q1 & 59 & $17 \%$ \\
\hline & Q2 & 50 & $14.40 \%$ \\
\hline & Q3 & 40 & $11.50 \%$ \\
\hline & Q4 & 40 & $11.50 \%$ \\
\hline & S1 & 24 & $6.90 \%$ \\
\hline & S2 & 26 & $7.50 \%$ \\
\hline & S3 & 32 & $9.20 \%$ \\
\hline & S4 & 34 & $9.80 \%$ \\
\hline & S5 & 16 & $4.60 \%$ \\
\hline & S6 & 27 & $7.80 \%$ \\
\hline \multirow{2}{*}{$\begin{array}{c}\text { Usage of } \\
\text { Periodontal dressing }\end{array}$} & Yes & 80 & $23 \%$ \\
\hline & No & 268 & $77 \%$ \\
\hline
\end{tabular}

Table 2. Distribution of flap surgeries across different sites with and without the usage of periodontal dressing. (Q for quadrant and $S$ for sextant). Irrespective of sites majority of cases periodontal dressing is not used. Statistical analysis - Chi-Square Test; $\mathrm{p}=0.261$; statistically insignificant showing no significant association between site of surgery and choice of periodontal dressing.

\begin{tabular}{|c|c|c|c|c|c|c|}
\hline Site number & \multicolumn{2}{|c|}{ Periodontal Dressing } & \multirow{2}{*}{ Total } & \multicolumn{3}{|r|}{ Pearson Chi-Square } \\
\hline & Yes & No & & Value & df & Asymptotic Significance (2-sided) \\
\hline Q1 & 15 & 44 & 59 & \multirow{11}{*}{$11.214^{a}$} & \multirow{11}{*}{9} & \multirow{11}{*}{0.261} \\
\hline Q2 & 6 & 44 & 50 & & & \\
\hline Q3 & 10 & 30 & 40 & & & \\
\hline Q4 & 6 & 34 & 40 & & & \\
\hline S1 & 6 & 18 & 24 & & & \\
\hline S2 & 10 & 16 & 26 & & & \\
\hline S3 & 5 & 27 & 32 & & & \\
\hline S4 & 9 & 25 & 34 & & & \\
\hline S5 & 5 & 11 & 16 & & & \\
\hline S6 & 8 & 19 & 27 & & & \\
\hline Total & 80 & 268 & 348 & & & \\
\hline
\end{tabular}


Figure 2. Bar graph depicting the distribution of sites and usage of periodontal dressing with Q1 as the most commonly treated site for flap surgeries with the highest prevalence. $X$ axis represents the site treated ( $Q$ for quadrant and $S$ for sextant) and $Y$ axis represents the number of cases with or without the usage of periodontal dressing in each site. Blue colour represents 'dressing' and green represents 'no dressing'. There is no statistically significant difference in choice of dressing between different sites even though in the majority of cases dressing was not preferred. Chi square test, $\mathrm{p}=0.261$, statistically not significant.

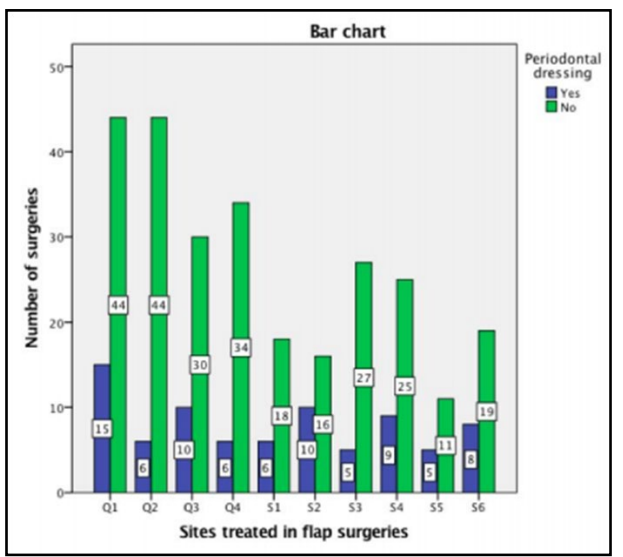

Table 3. Comparison of post operative healing index with respect to gender showing there is no significant difference in healing index between males and females. (Statistical analysis - Chi-Square Test; $\mathrm{p}=0.257$; statistically insignificant).

\begin{tabular}{|c|c|c|c|c|c|c|c|c|c|}
\hline & \multicolumn{5}{|c|}{ Post operative Healing Index } & & \multicolumn{3}{|c|}{ Pearson Chi-Square } \\
\hline Gender & Very Poor & Poor & Good & Very good & Excellent & Total & Value & df & $\begin{array}{l}\text { Asymptotic Signifi- } \\
\text { cance (2-sided) }\end{array}$ \\
\hline Female & 25 & 36 & 32 & 24 & 25 & 142 & \multirow{3}{*}{$5.311^{\mathrm{a}}$} & \multirow{3}{*}{4} & \multirow{3}{*}{0.257} \\
\hline Male & 21 & 60 & 58 & 36 & 31 & 206 & & & \\
\hline Total & 46 & 96 & 90 & 60 & 56 & 348 & & & \\
\hline
\end{tabular}

Figure 3. Bar graph showing post operative healing index between males and females, depicting not much variation between the genders. $\mathrm{X}$ axis represents the gender of patients and $\mathrm{Y}$ axis represents the number of cases with respective postoperative healing index scores. Blue colour represents '1-Very poor', green is '2-Poor', beige is '3-Good', purple is '4-Very good' and yellow is '5-Excellent'. However, this is statistically not significant, Chi square test, $\mathrm{p}=0.257$, statistically not significant.

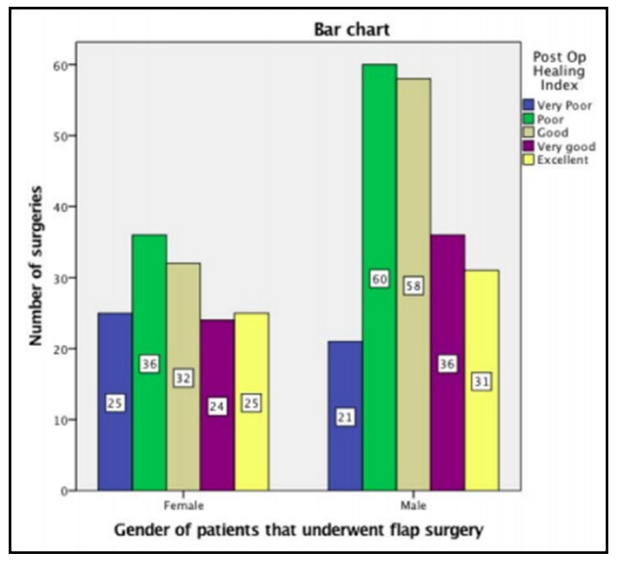

Table 4. Comparison of Post Op Healing Index ( qualitative score) for Flap Surgery with and without Periodontal dressing showing comparatively better healing for flap without periodontal dressing (Statistical analysis- Chi-Square Test; $\mathrm{p}=0.037$; statistically significant).

\begin{tabular}{|c|c|c|c|c|c|c|}
\hline \multirow{3}{*}{ Factor } & \multirow{3}{*}{$\begin{array}{l}\text { Healing } \\
\text { index }\end{array}$} & Usage & Periodontal & \multirow{2}{*}{\multicolumn{3}{|c|}{ Pearson Chi-Square }} \\
\hline & & \multicolumn{2}{|c|}{ Dressing for Flap surgery } & & & \\
\hline & & $\begin{array}{c}\text { Dressing } \\
\mathrm{N} \%\end{array}$ & $\begin{array}{c}\text { No Dressing } \\
\mathrm{N} \%\end{array}$ & Value & df & $\begin{array}{c}\text { Asymptotic Signifi- } \\
\text { cance (2-sided) }\end{array}$ \\
\hline \multirow{5}{*}{$\begin{array}{c}\text { Post op } \\
\text { Healing } \\
\text { Index after flap } \\
\text { surgery }\end{array}$} & Very poor & $8.49 \%$ & $3.43 \%$ & \multirow{5}{*}{$10.225^{a}$} & \multirow{5}{*}{4} & \multirow{5}{*}{0.037} \\
\hline & Poor & $18.86 \%$ & $18.62 \%$ & & & \\
\hline & Good & $32.54 \%$ & $24.63 \%$ & & & \\
\hline & Very good & $18.86 \%$ & $24.50 \%$ & & & \\
\hline & Excellent & $21.22 \%$ & $28.79 \%$ & & & \\
\hline
\end{tabular}


dressing was also calculated. The mean healing index for the "no dressing' group was found to be $3.04 \pm 1.26$ and for the group with periodontal dressing was $2.65 \pm 1.27$. The cases that did not use a periodontal dressing showed significantly better healing than the ones that used the dressing. On statistical analysis using independent $t$ test the difference was significant with $\mathrm{p}=0.015$ (Table 5, Figure 5).

\section{Discussion}

This study was carried out to check the preferences of dentists on the usage of periodontal dressings and to evaluate the effect of the dressings on post-operative pain, swelling and healing after flap surgery.

Usage of periodontal dressing was preferred $23 \%$ of the times amongst the dentists in our study (Table 1) and a significant association was obtained between postoperative healing and usage of periodontal dressing stating that 'no dressing' had significantly better healing than the usage of dressing in patients. (Figure 4,5)
A study conducted by Bose [23] supported the results of this study as on clinical evaluation they revealed more pronounced swelling and colour changes of gingiva in patients with dressing. He stated that periodontal dressing resulted in more inflammation immediately, post-surgically, which may delay the wound healing response as compared to patients without a dressing.

A number of clinical trials have proposed that the use of periodontal dressing accumulates plaque, causing inflammation [24, 25] irritates the healing tissues and also produces transient bacteraemia during post-operative dressing change [26] which causes more pain and swelling but less sensitivity and difficulty in eating $[22,27]$.

Periodontal dressings are applied around the necks of the teeth and adjacent tissues to cover and protect the surgical wound postperiodontal surgery. They serve as a bandage over the surgical site with the objective of holding the flap in place, protecting newly formed tissue, minimizing postoperative pain, infection and haemorrhage and supporting mobile teeth during the healing

Figure 4. Bar graph depicting the postoperative healing index between flap surgeries with or without the usage of periodontal dressing. More cases done without dressing shows excellent healing index scores. $\mathrm{X}$ axis represents the postoperative healing index and $\mathrm{Y}$ axis represents the number of cases in flaps with or without dressing with the respective healing index. Blue colour represents 'dressing' and red represents 'no dressing'. This relation is statistically significant, Chi square test, $\mathrm{p}=\mathbf{0 . 0 3 7}$, statistically significant.

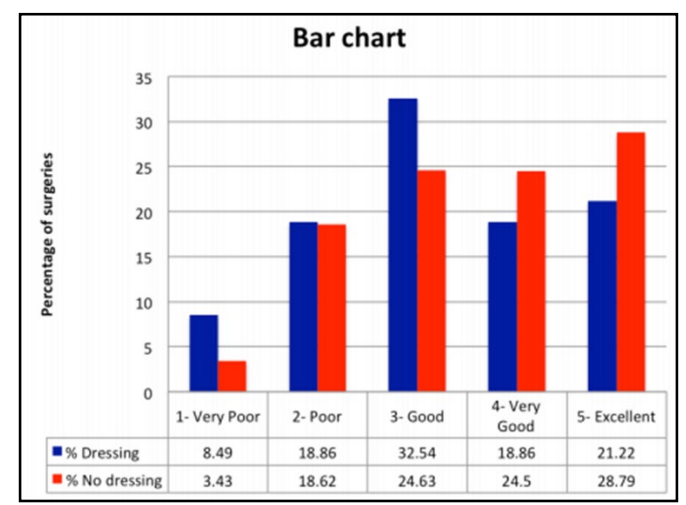

Figure 5. Graph showing the comparison of mean Post-operative healing index between flap surgeries done with or without periodontal dressing. $\mathrm{X}$ axis represents the usage of periodontal dressing and $\mathrm{Y}$ axis represents the mean healing index. Error bars indicate one standard deviation. No dressing (no pack) cases show significantly better healing. $\mathrm{p}=0.015$, with independent $\mathrm{t}$-test.

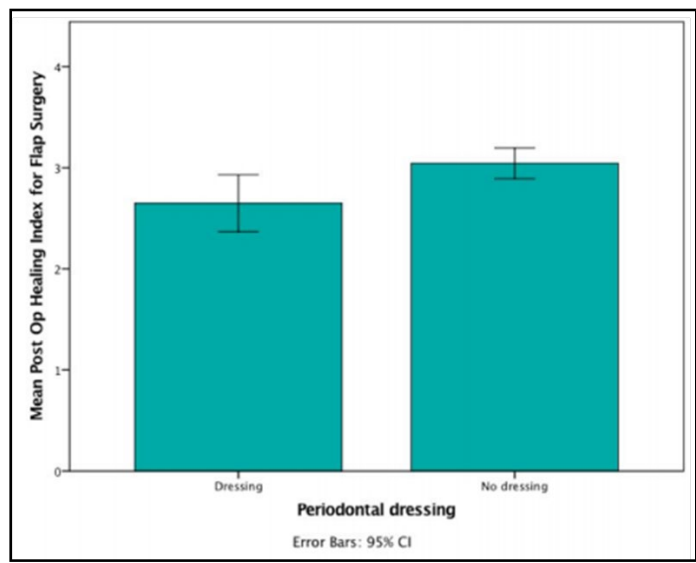

Table 5. Comparison of Postoperative healing index ( quantitative score) between flap surgeries with or without the usage of periodontal dressing showing higher mean healing index for flap without periodontal dressing ( statistical analysis using Independent $\mathrm{t}$ test $\cdot(\mathrm{p}=\mathbf{0 . 0 1 5}$; statistically significant $)$.

\begin{tabular}{|c|c|c|c|c|c|c|c|c|}
\hline & Group & $\mathbf{N}$ & Mean & Std. Deviation & Std. Error Mean & t & df & Sig. (2-tailed) \\
\hline \multirow{2}{*}{$\begin{array}{c}\text { Healing } \\
\text { index }\end{array}$} & Dressing & 80 & 2.65 & 1.274 & 0.142 & \multirow{2}{*}{-2.45} & 346 & 0.015 \\
\cline { 2 - 9 } & No dressing & 268 & 3.045 & 1.262 & 0.077 & & \\
\hline
\end{tabular}


process [28].

Hence many clinical trials were found to be opposing the results of this study that stated that 'no dressing' provided better healing. Soheilifar S [29] noted no significant difference between sites with and without periodontal dressings in terms of swelling, bleeding, gingival consistency, granulation tissue formation, gingival colour and ease of nutrition with $\mathrm{p}>0.005$. Similarly, no difference in three parameters were noticed by Jones TM [22] and Ghanbari $\mathrm{H}$ [19]. However, another study, revealed significantly more plaque accumulation and higher sulcus bleeding index on the dressing treated site at the end of the first postoperative week, thus supporting our statement $[5,21]$.

Since the current study is retrospective and done via digital case records, the post-operative healing could not be evaluated clinically. Hence, a healing index proposed by Landry, Turnhill and Howley [30] was used to describe the extent of clinical healing after periodontal surgery using post-operative photographs. Also, since in our study the healing was assessed immediately after the removal of the periodontal dressing from the surgical site, one week after the flap surgery was done, the early wound healing score [31] could not be evaluated like in other studies.

There is variability in the assessment of postoperative healing across the studies. Assessment of early wound healing was done by swelling of soft tissue, the colour of gingiva, volumetric GCF measurement and patient VAS score in one study [23]. The healing was evaluated during the first three days [29] after the first postoperative week, [21, 32] after two weeks [19] and 16 weeks [22] post-operatively in various studies. This could be a major reason why the results of the studies differ on the advocacy of usage of the periodontal dressing post-operatively, as the healing was evaluated at different intervals of time $[11,33]$.

The present study used a non-eugenol pack as the dressing similar to other studies $[19,20,22,32]$. Even though, eugenol-based dressing, were formerly popular especially following gingivectomy [34], due to their property of obtunding pain and retarding bacterial growth due to antiseptic properties; [35] they were found to irritate oral mucosal tissues, induce allergic reactions and cause tissue necrosis particularly in bone leading to delayed wound healing [36]. Histological evidence also showed greater tissue destruction with more inflammatory cell infiltration and corrective tissue response on usage of eugenol $[6,37]$. They were also found to inhibit fibroblast proliferation to a greater extent than non-eugenol dressings [38]. Due to these factors, non-eugenol dressings are currently more preferred than eugenol dressing.

Quadrant 1 was found to be the most commonly treated site for flap surgeries. (Table 1) No recent literature supports this finding but this hypothesis is probably due to the fact that right handed people brush more on the left side.

The present study also documented that males (59.2\%) have a higher prevalence of periodontal disease than females $(40.8 \%)$ (Table 1). This finding was supported by other studies that also depicted a higher prevalence of periodontitis in men $(\sim 57 \%)$ compared to women $(\sim 39 \%)[39,40]$, signifying a possible sex/ gender bias in disease pathogenesis. Based on post operative healing not much variation was observed between the genders (Figure 3, Table 3).
Loe and Silness [41] reported that exposed tissue heals irrespective of application of a protective dressing. The fact that complete healing can take place even without a dressing, provided the surgical area is kept clean, and that significant difference in healing was found in non-dressed sites, supports the theory that not all surgical sites need to be 'packed'.

This retrospective study based on hospital records had inherent limitations such as unknown criteria like how many patients were smokers and non smokers, surgical techniques being carried out by different surgeons and using different materials for suturing, but it did not have any major implications on our study due to the large sample size. It may have had a mild but negligible influence on the data. Since a calibrated single examiner carried out all the gradings for the healing index, there will not be any major discrepancies. Patient satisfaction was also not assessed as the study was done using digital case records.

Future scope of the study can be improved by conducting more controlled clinical trials with long term follow up.

\section{Conclusion}

It can be concluded that the majority of surgeons don't prefer the use of periodontal dressings (pack) after periodontal flap surgery and that the site of surgery and periodontal dressing preference is not related. Postoperative healing is significantly better for flap surgeries done without the periodontal dressing.

\section{Clinical Significance}

The clinical significance of this study is to identify if postoperative healing depends on the usage of a periodontal dressing or not.

\section{Acknowledgement}

We would like to thank the administration of Saveetha University, Chennai for granting us the clearance to conduct this study and for funding this research.

\section{Authors Contribution}

S.V contributed to study conception and design, data collection, analysis and interpretation and drafted the work. A.M. contributed to data interpretation, study design and data collection. R.J. contributed to study conception and design and data collection. All authors critically reviewed the manuscript and approved the final version.

\section{References}

[1]. Varghese SS, Thomas H, Jayakumar ND, Sankari M, Lakshmanan R. Estimation of salivary tumor necrosis factor-alpha in chronic and aggressive periodontitis patients. Contemp Clin Dent. 2015 Sep;6(Suppl 1):S152-6. Pubmed PMID: 26604566.

[2]. Khalid W, Vargheese SS, Lakshmanan R, Sankari M, Jayakumar ND. Role of endothelin-1 in periodontal diseases: A structured review. Indian J Dent Res. 2016 May-Jun;27(3):323-33.Pubmed PMID: 27411664.

[3]. Khalid W, Varghese SS, Sankari M, Jayakumar ND. Comparison of Serum Levels of Endothelin-1 in Chronic Periodontitis Patients Before and After 
Treatment. J Clin Diagn Res. 2017 Apr;11(4):ZC78-ZC81.Pubmed PMID: 28571268.

[4]. Mootha A, Malaiappan S, Jayakumar ND, Varghese SS, Toby Thomas J. The Effect of Periodontitis on Expression of Interleukin-21: A Systematic Review. Int J Inflam. 2016;2016:1-8.Pubmed PMID: 26998377.

[5]. Ramesh A, Varghese SS, Jayakumar ND, Malaiappan S. Chronic obstructive pulmonary disease and periodontitis-unwinding their linking mechanisms. J. Oral Biosci. 2016 Feb 1;58(1):23-6.

[6]. Priyanka S, Kaarthikeyan G, Nadathur JD, Mohanraj A, Kavarthapu A. Detection of cytomegalovirus, Epstein-Barr virus, and Torque Teno virus in subgingival and atheromatous plaques of cardiac patients with chronic periodontitis. J Indian Soc Periodontol. 2017 Nov-Dec;21(6):456-460.Pubmed PMID: 29551863.

[7]. Ramesh A, Varghese SS, Doraiswamy JN, Malaiappan S. Herbs as an antioxidant arsenal for periodontal diseases. J Intercult Ethnopharmacol. 2016 Jan 27;5(1):92-6.Pubmed PMID: 27069730.

[8]. Ramamurthy JA, Mg V. Comparison of effect of hiora mouthwash versus chlorhexidine mouthwash in gingivitis patients: a clinical trial. Asian J. Pharm. Clin. Res. 2018;11(7):84.

[9]. Avinash K, Malaippan S, Dooraiswamy JN. Methods of Isolation and Characterization of Stem Cells from Different Regions of Oral Cavity Using Markers: A Systematic Review. Int J Stem Cells. 2017 May 30;10(1):12-20. Pubmed PMID: 28531913.

[10]. Thamaraiselvan M, Elavarasu S, Thangakumaran S, Gadagi JS, Arthie T. Comparative clinical evaluation of coronally advanced flap with or without platelet rich fibrin membrane in the treatment of isolated gingival recession. J Indian Soc Periodontol. 2015 Jan;19(1):66-71.

[11]. Ravi S, Malaiappan S, Varghese S, Jayakumar ND, Prakasam G. Additive Effect of Plasma Rich in Growth Factors With Guided Tissue Regeneration in Treatment of Intrabony Defects in Patients With Chronic Periodontitis: A Split-Mouth Randomized Controlled Clinical Trial. J Periodontol. 2017 Sep;88(9):839-845.Pubmed PMID: 28474968.

[12]. Panda S, Jayakumar ND, Sankari M, Varghese SS, Kumar DS. Platelet rich fibrin and xenograft in treatment of intrabony defect. Contemp. Clin. Dent. 2014 Oct; $5(4): 550$

[13]. Ramesh A, Ravi S, Kaarthikeyan G. Comprehensive rehabilitation using dental implants in generalized aggressive periodontitis. J Indian Soc Periodontol. $2017 \mathrm{Mar} ; 21(2): 160-3$.

[14]. Ramesh A, Vellayappan R, Ravi S, Gurumoorthy K. Esthetic lip repositioning: A cosmetic approach for correction of gummy smile - A case series. J Indian Soc Periodontol. 2019 May-Jun;23(3):290-294.Pubmed PMID: 31143013

[15]. Ariaudo AA, Tyrrell HA. Repositioning and increasing the zone of attached gingiva. J. Periodontol. 1957 Apr;28(2):106-10.

[16]. Prichard JF. Present state of the interdental denudation procedure. J Periodontol. 1977 Sep;48(9):566-9.Pubmed PMID: 333089.

[17]. Wikesjö UM, Nilvéus RE, Selvig KA. Significance of early healing events on periodontal repair: a review. J Periodontol. 1992 Mar;63(3):158-65.

[18]. Baghani Z, Kadkhodazadeh M. Periodontal dressing: a review article. J Dent Res Dent Clin Dent Prospects. 2013;7(4):183-91.

[19]. Ghanbari H, Forouzanfar A, Fatemi K, Mokhtari M, Abrishami M, Ebrahiminik Z, et al. Modified Widman flap procedure: With or without periodontal dressing. Open J Stomatol. 2012 Sep 24;2(03):170-2.

[20]. MOGHAREH AA, Yaghini J, Tavakoli M, AMJADI MR, Najafian E. Evaluation of the effect of post-operative packing of gingiva on clinical signs and symptoms: a pilot study.JIDS.2011; 6(6): 705-71.

[21]. Newman PS, Addy M. A comparison of a periodontal dressing and chlorhexidine gluconate mouthwash after the internal bevelled flap procedure. J Periodontol. 1978 Nov;49(11):576-9.Pubmed PMID: 281487.

[22]. Jones TM, Cassingham RJ. Comparison of healing following periodontal surgery with and without dressings in humans. J. Periodontol.. 1979 Aug

\section{$1 ; 50(8): 387-93$}

[23]. Bose S, Gundannavar G, Chatterjee A, Mohan RR, Viswanath RA, Shetty S. Comparison Of The Early Wound Healing Following Periodontal Flap Surgery In Periodontitis Patients With And Without Periodontal Dressing. Indian Journal of Dental Sciences. 2013 Mar 1;5(1):25-29.

[24]. Heaney TG, Appleton J. The effect of periodontal dressings on the healthy periodontium. J. Clin. Periodontol. $1976 \mathrm{Mar} ; 3(1): 66-76$.

[25]. Newman PS, Addy M. Comparison of hypertonic saline and chlorhexidine mouthrinses after the inverse bevel flap procedure. J Periodontol. 1982 May;53(5):315-8.Pubmed PMID: 6953229.

[26]. Wampole HS, Allen AL, Gross A. The incidence of transient bacteremia during periodontal dressing change. J Periodontol. 1978 Sep;49(9):462-4. Pubmed PMID: 281493.

[27]. Greensmith AL, Wade AB. Dressing after reverse bevel flap procedures. J Clin Periodontol. 1974;1(2):97-106.Pubmed PMID: 4615111.

[28]. Kathariya R, Jain H, Jadhav T. To pack or not to pack: the current status of periodontal dressings. J Appl Biomater Funct Mater. 2015 Jul;13(2):73-86.

[29]. Soheilifar S, Bidgoli M, Faradmal J, Soheilifar S. Effect of Periodontal Dressing on Wound Healing and Patient Satisfaction Following Periodontal Flap Surgery. J Dent (Tehran). 2015 Feb;12(2):151-6.Pubmed PMID: 26056525.

[30]. Masse JF, Landry RG, Rochette C, Dufour L, Morency R, d'Aoust P. Effectiveness of soft laser treatment in periodontal surgery. Int. Dent. J. 1993 Apr 1;43(2):121-7.

[31]. Marini L, Rojas MA, Sahrmann P, Aghazada R, Pilloni A. Early Wound Healing Score: a system to evaluate the early healing of periodontal soft tissue wounds. J Periodontal Implant Sci. 2018 Oct 24;48(5):274-283.Pubmed PMID: 30405935.

[32]. Arunachalam D, Varghese SS. Comparison of Effectiveness of COE PAK and Barricaid with Respect to Wound Healing and Patient Satisfaction. Indian J Public Health Res Dev . 2019 Nov 1;10(11):3642.

[33]. Kavarthapu A, Thamaraiselvan M. Assessing the variation in course and position of inferior alveolar nerve among south Indian population: A cone beam computed tomographic study. Indian J Dent Res. 2018 JulAug;29(4):405-409.Pubmed PMID: 30127186.

[34]. O'neil TC. Antibacterial properties of periodontal dressings. J. Periodontol. 1975 Aug 1;46(8):469-74.

[35]. Waerhaug J, Loe H. Tissue reaction to gingivectomy pack. Oral Surg Oral Med Oral Pathol. 1957 Sep 1;10(9):923-37.

[36]. Sarrami N, Pemberton MN, Thornhill MH, Theaker ED. Adverse reactions associated with the use of eugenol in dentistry. Br. Dent. J. 2002 Sep;193(5):257-9.

[37]. Rivera-Hidalgo F, Wyan VJ, Horton JE. Effect of soluble extracts from periodontal dressings on human granulocytic leukocytes in vitro. J Periodontol. 1977 May;48(5):267-72.Pubmed PMID: 266076

[38]. Eber RM, Shuler CF, Buchanan W, Beck FM, Horton JE. Effect of periodontal dressings on human gingival fibroblasts in vitro. J. Periodontol. 1989 Aug;60(8):429-34.

[39]. Shiau HJ, Reynolds MA. Sex differences in destructive periodontal disease: a systematic review. J Periodontol. 2010 Oct;81(10):1379-89.Pubmed PMID: 20450376.

[40]. Eke PI, Dye BA, Wei L, Thornton-Evans GO, Genco RJ, CDC Periodontal Disease Surveillance workgroup: James Beck (University of North Carolina, Chapel Hill, USA), Gordon Douglass (Past President, American Academy of Periodontology), Roy Page (University of Washin. Prevalence of periodontitis in adults in the United States: 2009 and 2010. J Dent Res. 2012 Oct;91(10):914-20.

[41]. LOE H, SILNESS J. Tissue reactions to a new gingivectomy pack. Oral Surg Oral Med Oral Pathol. 1961 Nov;14:1305-14.Pubmed PMID: 14466176. 